\title{
PENYEDIAAN TEMPAT ISTIRAHAT PADA JALAN UMUM MELALUI CORPORATE SOCIAL RESPONSIBILIY
}

\author{
Hendra Hendrawan \\ Pusat Penelitian dan Pengembangan Jalan dan Jembatan, Jl. A.H Nasution 264 Ujung Berung Bandung, \\ Indonesia 40294. \\ e-mail : hendrawan@pusjatan.pu.go.id
}

\begin{abstract}
Rest Areas on non toll roads are road equipment that are not directly related to road users whose primary function is to reduce the number of accidents caused by driver and vehicle fatigue. This is in accordance with the agenda of the National General Plan of Road Safety (RUNK) to provide preventive infrastructure against potential accidents. To provide safe, convenient, secure, and sustainable rest areas, the government is faced with funding constraints. In the implementation, the construction of rest areas require funds that are not little, especially for land procurement and physical infrastructure development. For that reason, funding alternative is needed through Corporate Social Responsibility. This paper aimed to examine the feasibility of rest areas development through Corporate Social Responsibility by considering the aspect of legality and potential problems. The method used was literature review which included the aspects of feasibility, legality, and mechanism. The results showed that the rest areas can be part of Corporate Social Responsibility. The results of the study also indicated the need for additional tools in the form of regulations and guidelines to govern the partnership pattern so that development through this mechanism is well-running, supervised, and accountable
\end{abstract}

Key words : Corporate Social Responsibility, Feasibility, Non toll Road Rest Area.

\begin{abstract}
ABSTRAK
Tempat istirahat pada Jalan Umum merupakan perlengkapan jalan yang tidak berkaitan langsung dengan pengguna yang fungsi utamanya ditujukan untuk mengurangi jumlah kecelakaan akibat kelelahan baik pengemudi maupun kendaraan.Hal ini sesuai dengan agenda Rencana Umum Nasional Keselamatan Jalan untuk menyediakan prasarana yang bersifat preventif terhadap potensi terjadinya kecelakaan. Untuk menyediakan tempat istirahat yang selamat, nyaman, aman, dan berkelanjutan pemerintah dihadapkan pada kendala pendanaan. Dalam pelaksanaannya, pembangunan tempat istirahat memerlukan dana yang tidak sedikit terutama untuk pengadaan lahan dan pembangunan fisik infrastruktur. Untuk itu diperlukan alternatif pendanaan melalui Corporate Social Responsibility. Tulisan ini bertujuan untuk mengkaji kelayakan pembangunan melalui Corporate Social Responsibility dengan mempertimbangkan aspek legalitas dan potensi permasalahannya. Metode yang digunakan yaitu kajian literatur yang meliputi aspek kelayakan, legalitas, dan mekanismenya. Hasil kajian menunjukan tempat istirahat dapat menjadi bagian dari Corporate Social Responsibility. Hasil kajian juga menunjukan perlunya perangkat tambahan berupa regulasi dan pedoman yang mengatur pola kemitraan agar pembangunan melalui mekanisme ini berjalan, terawasi, dan akuntabe.,
\end{abstract}

Katakunsi : Corporate Social Responsibility, Kelayakan, Tempat Istirahat pada Jalan Umum.

\section{PENDAHULUAN}

Berbagai upaya dilakukan oleh
Pemerintah untuk mengurangi jumlah
kecelakaan baik berupa regulasi,
pembangunan/peningkatan infrastruktur
(fisik dan non fisik), maupun
penyuluhan/sosialisasi. Upaya yang

dilakukan pemerintah melalui regulasi diantaranya dengan menetapkan aturan penggunaan lampu utama kendaraan roda dua pada siang hari, penggunaan helm standar, penggunaan perlengkapan kendaraan, dan penetapan standar laik fungsi kendaraan dan jalan.. Dari aspek infrastruktur, pemerintah berupaya 
menerapkan efisiensi dan efektifitas alokasi anggaran yang tersedia melalui penyusunan skala prioritas penanganan jalan dengan memanfaatkan teknologi yang andal dan ramah lingkungan serta manajemen rekayasa lalu lintas guna memenuhi Standar Pelayanan Minimal (SPM) kinerja jalan dan kinerja sistem jaringan jalan. Sedangkan untuk upaya yang bersifat penyuluhan/sosialisasi, pemerintah menyampaikan iklan layanan masyarakat dan atau memberikan bimbingan kepada masyarakat agar memahami, dan mampu melaksanakan praktek-praktek berlalu lintas yang berkeselamatan baik ketika berada di ruang lalu lintas atau dalam kendaraan.

Dalam mewujudkan jalan yang berkeselamatan tersebut, pemerintah telah menetapkan tujuh arah dan tiga strategi untuk mewujudkan penyelenggaraan jalan yang berkeselamatan. ${ }^{1}$ Ketujuh arah tersebut diantaranya formalisasi dan standardisasi penanganan kecelakaan lalu lintas, sistem penjaminan bagi penyelesaian kerugian akibat kecelakaan lalu lintas, pendidikan keselamatan yang terarah dan penegakan hukum yang berefek jera, penyediaan pendanaan yang berkelanjutan guna peningkatan keselamatan jalan, pemberian hak mengemudi secara ketat, penyelenggaraan kelembagaan keselamatan jalan yang efektif yang didukung oleh sistem informasi yang akurat, dan penyediaan sarana dan prasarana lalu lintas yang memenuhi standar kelaikan keselamatan. Untuk mendukung arah kebijakan tersebut pemerintah telah menetapkan tiga strategi penyelenggaraan jalan yaitu penyelarasan arah dan komitmen penyelenggaraan keselamatan jalan dengan menkoordinir lima pilar secara inklusif, penyelenggaraan keselamatan jalan menggunakan pendekatan efisiensi biaya melalui tindakan kuratif dan preventif, dan pendekatan sistem keselamatan jalan yang mampu mengakomodasi human error dan kerentanan tubuh manusia. ${ }^{1}$

Upaya untuk mendukung arah kebijakan penyelenggaraan jalan yang berkeselamatan terutama terkait penyediaan sarana dan prasanana lalu lintas yang memenuhi standar keselamatan jalan, bersifat preventif, dan mengakomodasi human error dan kerentanan tubuh manusia yaitu melalui penyediaan perlengkapan jalan yang dapat mengurangi potensi terjadinya kecelakaan. Salah satu perlengkapan jalan yang dimaksud adalah tempat istirahat. $^{2}$

Tempat istirahat berdasarkan Peraturan Pemerintah No. 34 Tahun 2006 tentang Jalan merupakan perlengkapan jalan yang tidak berkaitan langsung dengan pengguna jalan, dengan fungsi untuk meningkatkan keselamatan pengguna jalan. ${ }^{3}$ Penyebab kecelakaan lalu lintas dapat disebabkan oleh beberapa faktor diantaranya faktor jalan (geometri dan struktur), kendaraan, lingkungan, dan manusia. ${ }^{4,5}$ Faktor manusia berdasarkan hasil penelitian yang dilakukan oleh Lum dan Reagen merupakan penyebab paling tinggi terjadinya kecelakaan. ${ }^{6}$ Contoh penyebab kecelakaan yang disebabkan faktor manusia diantaranya kelalaian, ketidaktaatan terhadap peraturan, kurangnya keterampilan dalam mengemudi dan kelelahan., ${ }^{7,8}$ Dari beberapa penyebab kecelakaan yang diakibatkan oleh faktor manusia, faktor kelelahan berada pada urutan pertama penyebab kecelakaan. ${ }^{8,9}$ Perlu upaya untuk mengurangi jumlah kecelakaan yang diakibatkan kelelahan. Transport Accident Commision mengatakan bahwa beristirahat merupakan cara efektif untuk mencegah kecelakaan yang disebabkan oleh kelelahan. $^{10}$

Ketentuan mengenai kewajiban beristirahat untuk pengemudi telah diatur dalam Undang-Undang No. 22 
Tahun 2009 tentang Lalu Lintas dan Angkutan Jalan Bagian Ketiga Waktu Kerja Pengemudi Pasal 90. ${ }^{11}$ Dalam pasal tersebut disebutkan bahwa pengemudi kendaraan bermotor umum wajib beristirahat paling singkat setengah jam setelah mengemudikan kendaraan selama 4 (empat) jam berturut-turut atau istirahat selama 1 (satu) jam setelah mengemudi selama 12 (dua belas) jam sehari. ${ }^{11}$ Untuk mendukung regulasi tersebut dan memfasilitasi agar pengemudi dapat beristirahat secara optimal, maka penyediaan tempat istirahat yang aman, nyaman, selamat, dan berkelanjutan menjadi sebuah keharusan. ${ }^{12}$

Penyelenggaraan tempat istirahat pada jalan tol wajib mengacu pada peraturan perundangan terkait jalan tol, termasuk didalamnya petunjuk teknis perencanaan dan pengelolaan tempat istirahat yang dikeluarkan oleh Badan Pengatur Jalan Tol (BPJT) sebagai lembaga yang memiliki sebagian wewenang pemerintah untuk mengatur, mengusahakan dan mengawasi penyelenggaraan jalan tol. ${ }^{13}$ Penyelenggaraan tempat istirahat pada jalan tol, umumnya dilaksanakan oleh mitra Badan Usaha Jalan Tol setelah melalui proses lelang. Adapun bentuk kerjasama antara BUJT dengan mitra yaitu dengan mekanisme Build Operate Transfer (BOT) atau Build Operate Own (BOO). ${ }^{14}$

Penyelenggaraan tempat istirahat yang berada pada jalan umum regulasinya harus mengacu pada peraturan perundangan jalan umum dan berada pada kewenangan penyelenggara jalan. Untuk perencanaan tempat istirahat pada jalan umum, Pusat Litbang Jalan dan Jembatan Kementerian Pekerjaan Umum dan Perumahan Rakyat telah menyusun pedomannya dan diharapkan dapat dijadikan sebagai acuan oleh semua penyelenggara jalan. ${ }^{12}$

Penyediaan tempat istirahat meskipun sudah didukung oleh regulasi dan pedoman teknis perencanaan, masih dihadapkan pada beberapa kendala diantaranya terkait pengelolaan dan pendanaan untuk pembangunan, operasional, dan pemeliharaan. Untuk pengelolaan, Nugroho dkk merekomendasikan alternatif kelembagaan dan standar pelayanan minimal. ${ }^{14}$ Pilihan alternatif kebijakan pengelolaan yaitu pelaksanaannya diselenggarakan oleh penyelenggara jalan sesuai kewenangannya atau melalui kerjasama pemerintah pusat dan daerah. Rekomendasi struktur organisasi lembaga pengelola yaitu Unit Pelaksana Teknis yang dipimpin oleh pejabat setingkat eselon IVa. Rekomendasi tersebut dipilih berdasarkan pertimbangan penyederhanaan struktur organisasi, efisiensi sumber daya, dan dukungan legalitas hukum dimana kewajiban penyediaan dan pengelolaan tempat istirahat ada pada penyelenggara jalan. Permasalahan lainnya yang muncul selain aspek pengelolaan yaitu pendanaan. Pembangunan tempat istirahat memerlukan biaya yang tidak sedikit untuk pengadaan tanah, pembangunan fasilitas, dan pengelolaan. Disisi lain, penyelenggara jalan masih dihadapkan pada keterbatasan pendanaan yang lebih difokuskan pada peningkatan dukungan konektivitas bagi penguatan daya saing dan peningkatan kemantapan jalan nasional dengan sasaran yaitu penurunan waktu tempuh pada koridor utama dari 2,7 jam per $100 \mathrm{~km}$ menjadi 2,2 jam per $100 \mathrm{~km}$, peningkatan pelayanan jalan dari 101 milyar kendaraan per km menjadi 133 milyar kendaraan per $\mathrm{km}$, dan peningkatan fasilitasi terhadap jalan daerah untuk mendukung kawasan dari $0 \%$ menjadi 100\%. ${ }^{15}$ Dengan keterbatasan dana tersebut, maka diperlukan peran dari swasta melalui berbagai kerjasama atau kebijakan/kepedulian sosial perusahaan 
melalui skema Corporate Social Responsibily (CSR).

CSR secara sederhana dapat didefinisikan sebagai tanggung jawab perusahaan yang berorentasi laba kepada seluruh stakeholders atau pemangku kepentingan untuk membangun sosial ekonomi kawasan secara holistik, melembaga dan berkelanjutan. ${ }^{16,17} \quad$ Pemangku kepentingan tersebut mencakup seluruh pemangku kepentingan yang berkonstribusi dan turut mempengaruhi output berupa barang atau jasa atau hasil akhir serta tujuan yang diinginkan dari pendirian suatu perusahaan (primary stakeholder), dan pemangku kepentingan yang dipengaruhi langsung atau tidak langsung dari aktivitas yang dilakukan oleh perusahaan (scondary stakeholders). ${ }^{18}$ Berdasarkan pemangku kepentingannya maka, tanggung jawab sosial mencakup tanggung jawab lingkungan internal atau operational responsibilities dan tanggung jawab sosial lingkungan eskternal atau citizenship responsibilities. ${ }^{17}$ Tanggung jawab internal diantaranya mencakup perlindungan terhadap kesehatan dan keselamatan kerja, perlakuan karyawan secara adil, perlindungan lingkungan kerja, pemenuhan kewajiban pajak, penjualan produk yang berkualitas dan terjangkau, penerapan standar produk dan lain sebagainya. Kemudian tanggung jawab eksternal diantaranya mencakup tanggap terhadap kebutuhan masyarakat, perlindungan lingkungan, perlindungan hak asasi manusia, pengembangan masyarakat, dan dukungan serta pelaksanaan kebijakan pemerintah untuk meningkatkan kesejahteraan masyarakat. ${ }^{17}$

Machmud telah melakukan kajian pemanfaatan dana CSR sebagai alternatif pembiayaan pembangunan daerah melalui analisis kelembagaan dan pemangku kepentingan yang terlibat, analisis regulasi dan kebijakan, analisis bentuk pelaksanaan, dan analisis sumber dan pola pendanaan. ${ }^{19}$ Terdapat beberapa langkah yang disarankan untuk mengoptimalkan alternatif sumber pembiayaan pembangunan daerah melalui CSR diantaranya pemetaan program $C S R$ berdasarkan wilayah, penguatan kelembagaan pemerintah desa, dan pembentukan forum pelaksana CSR. Selain itu mengacu pada riset yang telah dilaksanakan, $\quad 90 \%$ perusahaan merekomendasikan adanya sinkronisasi kegiatan dengan pemerintah dan 60\% perusahaan merekomendasikan adanya desain program CSR. ${ }^{19}$

Program CSR sudah banyak diimplementasikan untuk pembangunan infrastrukur publik diantaranya penyediaan air bersih, sanitasi, irigasi, jalan, pendidikan, dan kesehatan. Agar suatu proyek dapat diimplementasikan dengan baik, yaitu berhasil mencapai tujuan yang diharapkan secara efisien dan efektif, maka diperlukan suatu analisis kelayakan. Berdasarkan hal tersebut, studi ini memiliki dua tujuan yaitu:

a) Menganalisis kelayakan pembiayaan pembangunan tempat istirahat melalui skema CSR

b) Menganalisis aspek legalitas, dan mekanisme pelaksanaan CSR untuk pembangunan tempat istirahat.

\section{METODE PENELITIAN}

Studi ini menggunakan metode deskriptif kualitatif yaitu dengan membuat gambaran mengenai situasi dari objek yang diteliti dengan tujuan untuk menjawab suatu permasalahan yang ingin dipecahkan. Untuk menjawab permasalahan tersebut, studi memanfaatkan data sekunder yang diperoleh dari berbagai literatur. Literatur yang digunakan mencakup aspek hukum, implementansi, permasalahan, dan evaluasi terhadap penerapan CSR. Artikel-artikel terkait 
dikumpulkan, dicatat, dan dilakukan verifikasi dan teriangulasi terhadap sumber data lainnya agar tetap relevan dengan studi yang sedang dikaji. Secara garis besar, metode untuk menjawab tujuan studi dapat dilihat pada Gambar 1.

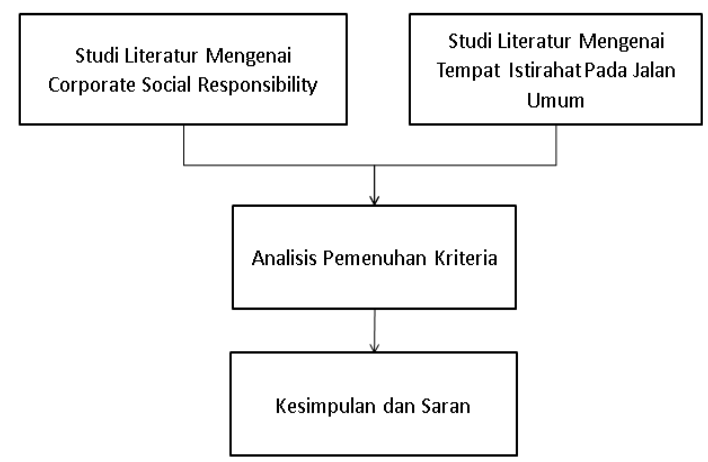

Gambar 1. Kerangka Kerja Studi

Studi literatur dilakukan untuk memperoleh informasi atau teori yang relevan dengan topik. Melalui studi literatur, diharapkan dapat mengetahui dan mengkaji mengenai permasalahan, pengalaman, dan teori-teori yang mendukung untuk menjawab permasalahan.

Dalam studi ini ada empat aspek yang dikaji diantaranya legalitas hukum, manfaat dari penyediaan tempat istirahat ditinjau dari aspek ekonomi, sosial, dan lingkungan, identifikasi pemangku kepentingan, manfaat bagi korporat, dan terakhir mekanisme implementasi CSR untuk pembiayaan tempat istirahat. Masing-masing aspek tersebut dianalisis secara komprehensif untuk dapat ditarik kesimpulan serta dibuatkan rekomendasi untuk dapat ditindak lanjuti melalui kebijakan atau studi lanjutan.

Tujuan dari stui literatur yaitu untuk mengevaluasi pemenuhan kriteria yang diperlukan agar penyediaan tempat istirahat dapat didanai melalui program CSR tanpa menimbulkan permasalahan baru baik dari sisi regulasi sampai dengan tahapan implementasi. Sumber referensi yang mutakhir dan relevan merupakan kunci dari studi literatur dalam studi ini.
Hasil dari studi literatur selanjutnya digunakan untuk menarik kesimpulan sejauh mana dukungan regulasi, dan prinsip-prinsip CSR dapat diterapkan untuk mendukung pelayanan publik melalui pembangunan tempat istirahat pada jalan umum yang memenuhi standar guna mengatasi permasalahan kecelakaan.

\section{HASIL dan PEMBAHASAN}

Analisis kelayakan merupakan bagian dari upaya untuk menilai layak tidaknya suatu aktivitas atau tindakan dilakukan baik dalam bentuk investasi langsung melalui pembangunan atau invenstasi tidak langsung melalui pemberian pinjaman atau pendanaan Tujuan dari analisis kelayakan yaitu untuk mengurangi resiko ketidak efisienan atau ketidakefektifan dari suatu aktivitas guna memperoleh hasil atau manfaat baik ekonomi atau sosial yang diharapkan dalam rentang waktu tertentu sesuai rencana.

Analisis kelayakan dapat dilakukan pada berbagai tahapan siklus program atau kegiatan. Sebagai contoh pemilihan lokasi, pembiayaan untuk pembangunan, pemilihan teknologi, pemilihan sumber daya (material dan tenaga kerja), dan lain-lain. Semakin besar skala investasi maka semakin penting analisis ini dilakukan yang dimulai dari tahap pendahuluan sampai dengan tahap keseluruhan kegiatan. Ada beberapa faktor yang mempengaruhi intensitas studi kelayakan diantaranya besarnya biaya yang diperlukan, tingkat ketidakpastian atau resiko, dan kompleksitas elemen yang mempengaruhi aktivitas atau kegiatan. $^{20}$

Berdasarkan hal tersebut, dari berbagai evaluasi yang pernah dilakukan melalui studi maka setidaknya ada tiga analisis kelayakan yang perlu dilakukan untuk pembangunan tempat istirahat yaitu pemilihan lokasi, skema pembiayaan, dampak atau manfaatnya terhadap triple 
bottom line (profit, people dan planet) dan pengelolaan. ${ }^{21}$ Analisis itu diperlukan dengan berbagai pertimbangan yaitu:

- Pemilihan lokasi menentukan tingkat efisiensi dan efektifitas penyediaan tempat istirahat dan mengurangi potensi resiko munculnya permasalahan dikemudian hari..

- $\quad$ Penyediaan tempat istirahat dapat menjadi kegiatan yang belum prioritas dalam mewujudkan jalan berkeselamatan. Keterbatasan dana menjadi kendala pembangunan. Untuk itu diperlukan alternatif pembiayaan yang didukung oleh regulasi yang kuat dan kejelasan mekanismenya.

- Analisis kelayakan untuk penyediaan infrastruktur menjadi sangat penting untuk skala investasi yang semakin besar. Pembangunan tempat istirahat memerlukan investasi yang tidak sedikit untuk pengadaan lahan dan pembangunannya. Nilai investasi yang diperlukan dipengaruhi oleh tipe tempat istirahat, dan fasilitas tambahan yang dibutuhkan.

- Sistem pengelolaan mempengaruhi efisiensi sumber daya dan efektivitas suatu layanan. Hal yang harus diperhatikan bahwa terdapat beberapa fasilitas layanan yang harus diberikan secara cumacuma yaitu toilet, taman, mushola, dan area parkir. Dengan demikian diperlukan bentuk kelembagaan yang ramping untuk menekan sumber daya yang diperlukan.

Dari uraian diatas analisis kelayakan pembiayaan merupakan bagian penting untuk mendukung pembangunan tempat istirahat. Salah satu sumber pembiayaan yang ditawarkan yaitu melalui program CSR. Ada beberapa hal yang perlu dianalisis sebelum diperoleh justifikasi bahwa pembangunan tempat istirahat layak dibiayai oleh skema ini yaitu:

- $\quad$ Legalitas hukum;

- Manfaat dan dukungan terhadap isu keberlanjutan;

- $\quad$ Pemangku kepentingan yang terlibat dan pembagian peran; dan Mekanisme implementasi.

\section{Legalitas hukum pembiayaan tempat istirahat melalui skema $C S R$}

Penyediaan infrastruktur publik merupakan kewenangan pemerintah. Namun, tidak semua infrastruktur publik menjadi tanggung jawab pemerintah terutama yang berkaitan dengan upaya untuk mengatasi eksternalitas atau dampak negatif terhadap publik yang diakibatkan oleh aktivitas kegiatan korporat atau perusahaan.

Dampak tersebut dapat berupa dampak ekonomi, sosial, dan atau lingkungan. Berdasarkan alasan tersebut, skema CSR merupakan hal yang wajib pada tataran penanganan dampak negatif dan pemenuhan regulasi dari keberadaan aktivitas perusahaan, dan dapat bersifat voluntari pada tataran selain itu. Kewajiban pelaksanaan CSR di Indonesia diatur dalam beberapa regulasi diantaranya:

1. Undang-Undang No. 22 Tahun 2001 tentang Minyak Gas dan Bumi Pasal 11 ayat 3 dan Pasal 40 ayat $5 .^{22}$

2. Undang-undang No. 40 Tahun 2007 tentang Perseroan Terbatas Pasal 1 angka 3, dan Pasal $74 .^{23}$

3. Undang-undang No. 25 Tahun 2007 tentang Penamaman Modal Pasal 15 huruf b , dan Pasal $16 .^{24}$

4. Undang-Undang No. 32 Tahun 2009 tentang Perlindungan dan Pengelolaan Lingkungan Hidup Pasal 68. ${ }^{25}$

5. Peraturan Pemerintah No. 47 Tahun 2012 tentang Tanggung 
Jawab Sosial dan Lingkungan Perseroan Terbatas. ${ }^{26}$

6. Peraturan Menteri Badan Usaha Milik Negara No. PER08/MBU/2013 Tahun 2013 Tentang Perubahan Keempat Atas Peraturan Menteri Negara Badan Usaha Milik Negara No. PER05/MBU/2007 Tentang Program Kemitraan Badan Usaha Milik Negara Dengan Usaha Kecil Dan Program Bina Lingkungan. Peraturan CSR dapat dilihat pada Pasal 1 dan Pasal 2. ${ }^{27}$

Beberapa catatan penting terkait regulasi diatas, dari yaitu:

1. Kewajiban CSR tidak hanya terbatas untuk perseroan, meskipun terdapat regulasi khusus yang mewajibkan CSR untuk perseroan yang mengelola dan memanfaatkan sumber daya atau aktivitasnya berdampak pada daya dukung lingkungan. ${ }^{23,28}$

2. Kewajiban CSR tidak terbatas hanya untuk perusahaan besar, tetapi untuk seluruh perusahaan untuk meminimalisir dampak. ${ }^{17,24}$

3. Kewajiban CSR tidak terbatas pada bisnis inti, tetapi dapat dilaksanakan diluar bisnis inti setelah kewajiban penanganan atau minimalisir dampak akaibat kegiatan perusahaan telah dilaksanakan. ${ }^{22,24,28}$

4. Kewajiban CSR tidak terbatas pada pelaku langsung tetapi termasuk perusahaan yang tidak terlibat secara langsung seperti perbankan, pemasok, dan bahkan mitra bisnisnya. Dengan demikian kegiatan CSR tidak terbatas pada aktivitas langung penanganan dampak, tetapi turut mendorong dan memasarkan kegiatan CSR adalah salah satu bentuk aktivitas CSR itu sendiri. ${ }^{17}$

5. Perusahaan tidak dianggap melakukan aktivitas CSR apabila terdapat peraturan atau regulasi yang dilanggar. ${ }^{29}$

Dalam implementasinya, Rahmatullah menyarankan diperlukan regulasi khusus yang mengatur mengenai kemitraan pemerintah dan perusahaan untuk mengelola program $C S R .^{30}$

\section{Manfaat dan dukungan terhadap isu keberlanjutan}

Dalam implementasinya, pelaksanaan CSR menurut harus memenuhi tiga prinsip yaitu: ${ }^{17}$

- $\quad$ Corporate Social Responsiveness, yaitu tanggap terhadap isu sosial. Prinsip ini wajib dijalankan untuk memperoleh dukungan dari pemerintah dan masyarakat dalam menjalankan aktivitasnya.

- Corporate Governance, yaitu keberhasilan memperoleh laba atau manfaat dari aktivitasnya. CSR tidak lagi dipandang sebagai beban, tetapi merupakan bagian dari implementasi pemasaran holistik melalui proses peningkatan sumber daya internal, komunikasi produk dan nilainilai, perlindungan terhadap konsumen dengan memperhatikan etika, lingkungan, hukum, dan konteks sosial untuk meningkatkan kesejahteraan bersama, dan membangun hubungan kerjasama yang saling menguntungkan dengan berbagai pemangku kepentingan.

- Corporate Citizenship yaitu melakukan berbagai macam kebajikan sebagai warga negara yang baik.

Selain itu, empat komponen yang harus diperhatikan dalam penerapan konsep CSR yaitu: ${ }^{17}$

- Economic Responsibilites. Tanggung jawab untuk menghasilkan barang atau jasa untuk memperoleh nilai manfaat atau laba bagi perusahaan. 
- $\quad$ Legal Responsibilities. Tanggung jawab untuk mentaati hukum.

- $\quad$ Ethical Responsbilities. Tanggung jawab untuk menghasilkan barang atau jasa yang bermanfaat dan atau bernilai bagi masyarakat dan menjalankan etika bisnis yang baik.

- Discretionary Responsibilities. Tanggung jawab untuk memberikan manfaat bagi masyarakat sekitarnya.

Ketiga prinsip dan komponen diatas merupakan landasan dalam menjalankan CSR yang sekaligus merupakan implementasi atau bagian yang tidak terpisahkan dari konsep pembangunan berkelanjutan (sustainability development). ${ }^{29}$ Dengan demikian pemenuhan prinsip-prinsip berkelanjutan yang mencakup aspek ekonomi, sosial, dan lingkungan, merupakan keharusan untuk menilai kelayakan pembangunan tempat istirahat melalui skema CSR.

Untuk menjawab kebutuhan tersebut, tempat istirahat dikembangan melalui konsep Anjungan Pelayanan Jalan. Tempat istirahat dengan konsep APJ selain ditujukan upaya untuk mengurangi jumlah kecelakaan lalu lintas juga dimanfaatkan sebagai pusat unit reaksi cepat untuk preservasi jalan dan peningkatan ekonomi masyarakat setempat dan daerah. Terdapat lima prinsip perencanaan tempat istirahat untuk mendukung konsep Anjungan Pelayanan Jalan diantaranya: ${ }^{31}$

- $\quad$ Pemenuhan peraturan perundangundangan dan persyaratan teknik jalan dan teknik bangunan/gedung

- Keamanan, keselamatan, dan kemudahan bagi pengguna jalan dan pengguna tempat istirahat

- Kebutuhan pengguna jalan, penyelenggara jalan dan masyarakat lokal,

- Kesesuaian tujuan pembangunan tempat istirahat dengan rencana pengembangan induk sektoral dan wilayah

- Keterlibatan seluruh pemangku kepentingan baik pemerintah, swasta dan masyarakat.

Kelima prinsip tersebut diterjemahkan kedalam aktivitas perencanaan mulai dari pemilihan lokasi, sampai dengan penentuan fasilitas dan kapasitas fasilitas. Untuk itu, terkait proses pemilihan lokasi terdapat hal-hal yang harus diperhatikan yaitu: ${ }^{31}$

- Keselamatan dan kemudahan pengguna jalan dan pengguna tempat istirahat

- $\quad$ Kesesuaian lokasi tempat istirahat dengan penataan ruang dan perizinan lingkungan

- Keberlanjutan dan efisiensi penyediaan tempat istirahat

- $\quad$ Kesesuaian lokasi tempat istirahat dengan rencana pembangunan.

Adapun fasilitas yang disediakan yaitu tempat istirahat, pos manajemen jalan, pos tanggap darurat, pusat informasi, fasilitas umum, dan ikubator ekonomi lokal. Masing-masing kebutuhan untuk jenis dan kapasitas fasilitas dianalisis dengan tetap memperhatikan batas minimal yang perlu disediakan agar pelayanan masih dalam standar yang layak (manusiawi).

Kotler dan Lee menyebutkan ada enam kategori aktivitas CSR yaitu cause promotoions, cause related marketing, corporate societal marketing, corporate philantropy, community volunteering, dan social responsible business practise. Kategori aktivitas itu apabila dikaitkan dengan aktivitas yang dapat dilakukan di tempat istirahat dengan konsep APJ yaitu: ${ }^{32}$

1. Couse Promotions. Perusahaan meningkatkan kesadaran nilai dan isu-isu sosial, misal terkait pelestarian lingkungan, budaya, dan keselamatan lalu lintas dengan memanfaatkan fasilitas informasi. 
2. Cause Related Marketing. Pemasaran terkait kegiatan sosial. Perusahaan melakukan kegiatan sosial dengan menyumbangkan penghasilannya untuk kegiatan sosial. Misal memberikan layanan kesehatan cuma-cuma atau memberikan minuman atau makanan yang mampu meningkatkan daya tahan atau memulihkan kondisi pengemudi.

3. Corporate Social Marketing. Pemasaran Kemasyarakatan Korporat. Perusahaan mengajak atau melaksanakan kampanye untuk meningkatkan kesehatan, keselamatan (diantaranya dilingkungan jalan, dan tempat kerja), kelestarian lingkungan, dan partisipasi masyarakat dalam kegiatan sosial.

4. Corporate Philantropy.

Perusahaan melakukan kegiatan aksi sosial langsung baik dalam bentuk pemberian layanan atau bantuan keuangan cuma-cuma. Misal memberikan bantuan keuangan untuk petani atau perajin yang menjual produk lokal khas daerah setempat.

5. Socially Responsible Business Practice. Perusahaan dapat melakukan kegiatan yang mencakup penyedian fasilitas yang memenuhi standar keamanan, keselamatan, dan ramah lingkungan.

Tabel 1. Menunjukan dukungan penyediaan tempat istirahat dengan konsep anjungan pelayanan jalan terhadap prinsip-prinsip berkelanjutan. Manfaat dan dukungan penyediaan keberlanjutan pada Tabel 1 dapat dicapai dengan hasil yang optimal apabila dimulai dengan mengidentifikasi kebutuhan, pemangku kepentingan yang akan terlibat, dan manfaat atau hasil yang ingin dicapai oleh perusahaan. Dengan identifikasi tersebut, perusahaan dapat memilih dengan tepat jenis kegiatan yang akan dilakukan sesuai dengan dampak dari aktivitas, produk yang dipasarkan atau manfaat yang ingin dicapai oleh perusahaan.

\section{Pemangku kepentingan dan pembagian peran}

Identifikasi dan dialog antar pemangku kepentingan merupakan bagian penting yang harus dilaksanakan agar skema CSR dapat berjalan dengan baik. ${ }^{29}$ Pemangku kepentingan dapat berasal dari internal pelaku (inside actors) atau eksternal pelaku (outside actors). ${ }^{33}$ Untuk penyediaan tempat istirahat yang kewenangannya ada pada penyelenggara jalan (pemerintah), maka pemangku kepentingan internal (internal stakeholders) adalah seluruh jajaran atau organisasi yang terdapat di lingkungan pemerintah yang turut mempengaruhi hasil keputusan atau memperoleh dampak atau manfaat dari penyediaan tempat istirahat. Sedangkan pemangku kepentingan eksternal (external stakeholders) adalah perusahaan, masyarakat lokal, lembaga sosial masyarakat, dan pengguna jalan yang secara langsung atau tidak langsung berkontribusi, terkena dampak atau menerima manfaat dari keberadaan tempat istirahat.

Berdasarkan konsep CSR yang sudah diutarakan di muka, maka pemangku kepentingan yang perlu didorong untuk berinvestasi dalam pengadaan fasilitas tempat istirahat merupakan perusahaan yang memberikan dampak terhadap lalu lintas atau masyarakat yang kegiatan perekonomiannya tergantung pada interaksi dengan pengguna jalan. Sebagai contoh, perusahaan yang bergerak dibidang otomotif yang merupakan bagian dari rantai pasok turut berkontribusi terhadap peningkatan jumlah pengguna kendaraan bermotor pribadi. Dampak dari aktivitas pemasaran mereka terkait dengan peningkatan volume lalu lintas dan pada kondisi tertentu potensi kecelakaan dapat terjadi. Di bidang lain, perusahaan pengembang jalan jalan tol dapat mengakibatkan penurunan pendapatan masyarakat lokal daerah setempat yang menjual oleh-oleh khas daerah setempat.

Selanjutnya dari keseluruhan pemangku kepentingan terlibat, dilakukan identifikasi peran dari masing-masing pemangku kepentingan. Kartini menyarankan 
dibentuknya Badan Perencana CSR, Badan Pelaksana CSR dan Badan Pengendali CSR. ${ }^{17}$ Masing-masing dari badan tersebut diwakili oleh unsur pemerintah, perusahaan, masyarakat, dan lembaga pengelola. Masing-masing dari pemangku kepentingan tersebut dapat pula membentuk substruktur organisasi masingmasing untuk menjalakan perannya. Adapun Peran masing-masing dari stakeholder dapat dilihat pada Tabel 2.

Terkait struktur organisasi untuk pengelolaan tempat istirahat yang dilaksanakan oleh pemerintah, pemerintah dapat membentuk UPT pengelola tempat istirahat. Adapun jika pengelolaan akan diserahkan kepada masyarakat, lembaga pengelola dapat berbentuk koperasi. Keseluruhan struktur organisasi atau lembaga tersebut perlu diwadahi dalam satu lembaga induk yang akan mengatur pola kemitraan dan pembagian peran secara jelas.

Dalam aktivitas penyelenggaraan tempat istirahat partisipasi aktif dan kerjasama seluruh pemangku kepentingan diperlukan. Melalui partisipasi aktif, sasaran kegiatan yang dilaksanakan oleh perusahaan seharusnya sesuai dengan kebutuhan masyarakat atau isu sosial yang sedang berkembang. Perusahaan dapat menyusun rencana kegiatan dengan baik termasuk didalamnya menyusun rencana fasilitas yang perlu disediakan dalam tempat istirahat.

\section{Mekanisme implementasi}

Wang et al mengatakan ada 4 aspek yang mendorong penerapan atau implementasi CSR dibeberapa negara yaitu: ${ }^{34}$

1) regulasi yang memaksa program CSR dilaksanakan

2) keinginan untuk meningkatkan profit, meningkatkan daya saing, memotivasi pekerja, dan peningkatan citra perusahaan, dll (Faktor internal)

3) Dorongan dari pihak luar atau tuntutan masyarakat

4) Budaya atau nilai setempat

Sedangkan untuk model penerapan CSR, umumnya ada empat model penerapan CSR yaitu: ${ }^{35}$

1) Perusahaan menjalankan sendiri program CSR tanpa melalui perantara. Perusahaan dapat membentuk sendiri struktur organisasi perencana, pelaksana, dan pengendali kegiatan atau menugaskan salah satu pejabat seniornya.

2) Perusahaan membentuk yayasan atau organisasi sosial perusahaan

3) Perusahaan melakukan kemitraan dengan pemerintah, Lembaga Sosial Masyarakat (LSM), lembaga pendidikan, lembaga kesehatan, dan lainnya.

4) Perusahaan bergabung dalam konsorsium, atau anggota dalam suatu lembaga sosial yang sudah berdiri

Dari keempat model tersebut, pola kemitraan dimana pelaksanaannya merupakan kewajiban pemerintah, maka pola kemitraan merupakan model CSR yang lebih baik. Namun dalam pelaksanaannya, untuk mencegah terjadinya pola kemitraan yang kontra atau semi produktif, maka ada tiga prinsip yang harus dilaksanakan untuk membangun pola kemitraan yang baik yaitu: ${ }^{33}$

1) Kesetaraan (Equity). Pemangku kepentingan saling menghormati, menghargai, dan mempercayai

2) Transparansi. Pemangku kepentingan saling terbuka dalam pengelolaan informasi dan keuangan

3) Saling menguntungkan. Pemangku kepentingan memberikan manfaat bagi semua pihak.

Untuk membangun kemitraan yang memenuhi ketiga prinsip tersebut diperlukan kerjasama seluruh pemangku kepentingan. Sebagaimana diutarakan sebelumnya, kerjasama pemangku kepentingan merupakan bagian penting dalam implementasi CSR. Masing-masing pemangku kepentingan harus dapat menjalankan peran dan tugasnya dengan penuh tanggung jawab dan bersinergi satu sama lain. Agar dapat bersinergi maka diperlukan sinkronisasi antara pemerintah dan perusahaan dalam tahapan implementasi program.

Hurairah menyatakan ada enam tahapan dalam pelaksanaan pengembangan masyarakat yang meliputi identifikasi kebutuhan, rencana tindakan, pelaksanaan, monitoring dan eveluasi, penyelesaian atau 
penyerahan program, dan rencana tindak lanjut paska program. ${ }^{36}$ Adapun untuk tahapan implementasi tempat istirahat ada beberapa tahap yang harus dilaksanakan yaitu:

1) Identifikasi kebutuhan.

Pemilihan lokasi tempat istirahat berdasarkan prinsip dan kriteria pemilihan lokasi yang sudah ditetapkan dalam pedoman.

2) Indentifikasi pemangku kepentingan. Pertimbangan pemilihan pemangku kepentingan mencakup: ${ }^{37}$

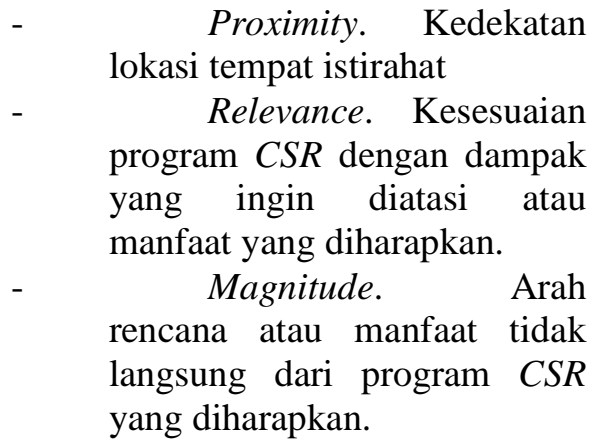

3) Penyusunan kelembagaan.

Kelembagaan diperlukan sebagai bagian dari keberlanjutan dan untuk memperjelas peran masing-masing pemangku kepentingan. Dalam pelaksanaannya masing-masing pemangku kepentingan dalam membentuk struktur organisasi tersendiri untuk melaksanakan dan mengendalikan peran yang sudah disepakati

4) Penyusunan program.

Pelibatan keseluruhan pemangku kepentingan melalui pola kemitraan. Peningkatkan partisifasi aktif untuk mensinergikan program-program sesuai peran masing-masing pemangku kepentingan termasuk didalamnya terkait pendanaan.

5) Pelaksanaan program.

Tahapan pelaksanaan mulai dari pembangunan, pemanfaatan dan operasionalisasi, dan pemeliharaan.

6) Evaluasi dan Monitoring

Pengendalian dan pengawasan terhadap pelaksanaan program agar sesuai rencana. Mengidentifikasi masalah dan memperoleh umpan balik atas kegiatan yang sudah dilaksanakan

7) Pelaporan
Melaporkan pertanggungjawaban atas pelaksanaan program untuk dapat dimanfaatkan dalam penyusunan rencana tindak lanjut pengelolaan.

Tahapan selanjutnya setelah pelaporan yaitu penyusunan kembali rencana atau memulai kembali pada langkah 4. Untuk mengukur kinerja implementasi CSR terdapat delapan indikator yang dapat digunakan yaitu: ${ }^{17}$

1) Kepemimpinan. Terdapat komitmen pemimpin pemerintah dan perusahaan dalam mendukung program penyediaan tempat istirahat dan aktivitas CSR didalamnya.

2) Transparansi dan akuntabilitas. Pemerintah dan perusahaan terbuka dalam penggunaan dana dan pelaporan pelaksanaan serta hasil yang dicapai

3) Proporsi bantuan. Alokasi dana yang dikeluarkan sesuai dengan kebutuhan dilapangan.

4) Cakupan wilayah. Program CSR dapat menjangkau target penerima manfaat yang diharapkan yaitu pengguna jalan dan masyarakat setempat.

5) Perencanaan, dan monitoring dan evaluasi. Dalam perencanaan adanya keterlibatan seluruh pemangku kepentingan, kesesuaian dengan budaya dan kearifan lokal. Dalam monitong dan evaluasi adanya kebijakan dan pembagian peran yang jelas.

6) Koordinasi pemangku kepentingan. Terdapat mekanisme yang jelas untuk melaksanakan koordinasi antar pemangku kepentingan.

7) Keberlanjutan. Terjadi alih peran dari perusahaan ke masyarakat, ada perasaan memiliki, dan ikut memelihara fasilitas yang ada.

Outcome. Program yang sudah dilaksanakan memberikan dampak nyata bagi masyarakat yaitu jumlah kecelakaan menurun, pelayanan publik jalan meningkat kinerjanya, dan masyarakat setempat lebih berdaya dan terjadi perbaikan kesejahteraan. 


\section{KESIMPULAN}

Berdasarkan kajian diatas maka dapat disimpulkan bahwa penyediaan tempat istirahat dapat diselenggarakan melalui program CSR berdasarkan isu keberlanjutan, manfaat, dan dukungan terhadap pemberdayaan masyarakat. Pelaksanaan program CSR untuk penyediaan fasilitas publik sudah memiliki payung hukum yang jelas, dan dalam implementasinya sudah terdapat beberapa contoh kasus serta pedoman dan petunjuk praktis pengelolaannya. Agar implementasi CSR dapat berjalan optimal maka dua hal penting yang harus diperhatikan yaitu identifikasi pemangku kepentingan dan keberadaan pedoman atau petunjuk teknis dari penyelenggara jalan yang mengatur pola kemitraan yang membagi jelas peran dari masing-masing pemangku kepentingan. Petunjuk teknis tersebut disusun bersama oleh pemerintah dan pemangku kepentingan.

\section{UCAPAN TERIMAKASIH}

Terima kasih diucapkan kepada Kepala Pusat Penelitian dan Pengembangan Jalan dan Jembatan, serta kepada Kepala Balai Sistem dan Teknik Lalu Lintas yang telah mendukung penelitian terkait pengelolaan tempat istirahat pada jalan umum dengan konsep APJ.

\section{DAFTAR PUSTAKA}

[1] Republik Indonesia, 2010. Rencana Umum Nasional Keselamatan (RUNK) Jalan 2011-2035. Jakarta.

[2] Pangihutan, Harlan., dan Hendrawan, Hendra. 2016. Model Pengelolaan Tempat Istirahat Pada Jalan Non Tol. Jurnal Jalan dan Jembatan. Volume 33 No. 2, JuliDesember 2016. 127:139

[3] Republik Indonesia, 2006. Peraturan Pemerintah Nomor 34 Tahun 2006 tentang Jalan. Jakarta: Sekretariat Negara

[4] Fadel, Muhammad., Muis, Masyitha., Russeng, Syamsiar.
2014. Faktor yang Berhubungan dengan Kelelahan Kerja Pengemudi Pengangkutan BBM di TBBM PT. Pertamina Parepare.Universitas Hasanuddin

[5] Sari, Windy Pranita., Mahyuni, Eka Lestarai., Salmah, Umi. 2015. Faktor-faktor Yang Mempengaruhi Potensi Kecelakaan Kerja Pada Pengemudi Truk di PT Berkatnugraha Sinarlestari Belawan Tahun 2015. Univesitas Sumatera Utara. Medan

[6] Lum, H., Reagen, J.A. 1995. Interactive Highway Safety Design Model: Accident Predictive Module. Public Roads Magazine, 59 (2): 1-6

[7] Damopoli, Farrah Ch., Kawatu, Paul A.T., dan Tumbol, Reiny A. 2013. Faktor-faktor yang berhubungan dengan kelelahan kerja pada supir bis trayek Manado Amurang di Terminal Malalayang Manado.

[8] Tjakranata, Lanny H. 1996. Tesis. Pengaruh Kelelahan Pengemudi Terhadap Frekuensi Kecelakaan Lalu lintas (Studi Kasus: Pengemudi Bus di Jalan Tol Jakarta-Cikampek)

[9] Umyati, Ani., Yadi, Yayan Harry., Sandi, Eka Setia Norma. 2015. Pengukuran Kelelahan Kerja Pengmudi Bis dengan Aspek Fisiologis Kerja dan Metode Industrial Fatique Research Commitee (IFRC). Seminar Nasional IENACO.

[10] Transport Accident Commission. 2017. Avoiding driver fatigue. (http://www.tac.vic.gov.au/roadsafety/safe-driving/tips-andtools/fighting-fatigue, diakses 25 September 2017)

[11]Republik Indonesia, 2009. UndangUndang No. 22 Tahun 2009 tentang Lalu Lintas dan Angkutan Jalan. Jakarta: Sekretariat Negara 
[12] Hendrawan, H., Pangihutan, $H$. Nugroho, A., Parbowo. 2016. Laporan Akhis Pendampingan Teknis Anjungan Pelayanan Jalan. Bandung: Pusjatan

[13] Republik Indonesia, 2005. Peraturan Pemerintah Nomor 15 Tahun 2005 tentang Jalan Tol. Jakarta: Sekretariat Negara

[14] Nugroho, A., Hendrawan, H., Pangihutan H. 2016, dan Sharfina, Winni. Naskah Kebijakan Anjungan Pelayanan Jalan. Bandung: Pusjatan

[15] Republik Indonesia, 2015. Rencana Strategis Kementerian Pekerjaan Umum dan Perumahan Rakyat Tahun 2015-2019. Jakarta: Kementerian Pekerjaan Umum dan Perumahan Rakyat.

[16] Suharto, Edi. (2006). Membangun Masyarakat Memberdayakan Rakyat Kajian Strategis Pembangunan Kesejahteraan Sosial dan Pekerjaan Sosial. Bandung : Aditama.

[17] Kartini, Dwi. 2013. Corporate Social Responsibility Transformasi Konsep Sustainability Management Dan Implementasi di Indonesia. Bandung: Refika Aditama.

[18] Post, James, E, and Lawrence, Anne T, and Weber, James, 2002. Business and Society: Corporate Strategy, Public Policy, Ethics, tenth Edition. McGraw Hill

[19]Machmud Senen. 2015. Kajian Pemanfaatan Dana Corporate Social Responsibility Sebagai Alternatif Sumber Pembiayaan Pembangunan Daerah. Jurnal Ekonomi, Bisnis \& Entrepreneurship Vol. 9 No. 1 April 2015, 29-44.

[20] PIMAC, 2008. General Guidelines for Preliminary Feasibility Studies (fifth edition).

[21] Engkington, J.1997. Cannibal With Forks: The Triple Bottom Line of 21st Century Business. Capstone Oxford

[22]Republik Indonesia. 2001. UndangUndang No. 22 Tahun 2001 tentang Minya Gas dan Bumi. Jakarta:Sekretariat Negara

[23] Republik Indonesia, 2007. Undangundang No. 40 Tahun 2007 tentang Perseroan Terbatas. Jakarta: Sekretariat Negara

[24] Republik Indonesia, 2007. Undangundang No. 25 Tahun 2007 tentang Penanaman Modal. Jakarta: Sekretariat Negara

[25] Republik Indonesia, 2009. UndangUndang No. 32 Tahun 2009 tentang Perlindungan dan Pengelolaan Lingkungan Hidup. Jakarta: Sekretariat Negara

[26]Republik Indonesia, 2012. Peraturan Pemerintah No. 47 Tahun 2012 tentang Tanggung Jawab Sosial dan Lingkungan Perseroan Terbatas

[27]Republik Indonesia, 2013. Peraturan Menteri Badan Usaha Milik Negara No. PER08/MBU/2013 Tahun 2013 Tentang Perubahan Keempat Atas Peraturan Menteri Negara Badan Usaha Milik Negara No. PER05/MBU/2007 Tentang Program Kemitraan Badan Usaha Milik Negara Dengan Usaha Kecil Dan Program Bina Lingkungan. Jakarta.

[28]Jalal. 2009. Kesalahpahaman tentang Tanggung Jawab Sosial Perusahaan. Diperoleh dari https://csrlingkunganindonesia.wor dpress.com/artikel-csr-

lingkungan/jalal/ [Diakses 22 September 2017]

[29]Franc, Pavel., Nezhyba, Jiri., Heydenreich, Cornelia. 2006. Taking Corporate Social Responsibility Seriously. Environmental Law Sevice 1st Edition.

[30]Rahmatullah. 2012. Model Kemitraan Pemerintah dengan 
Perusahaan Dalam Mengelola CSR: Studi Kasus Kota Cilegon. Jurnal Informasi, Vol.17. No.01: 36-47

[31] Republik Indonesia, 2016. Draft Pedoman Perencanan Tempat Istirahat Pada Jalan Umum (R4). Bandung: Pusat Litbang Jalan dan Jembatan Kementerian Pekerjaan Umum dan Perumahan Rakyat

[32] Kotler, Philip and Lee, Nancy. 2005. Corporate Social Responsibility: Doing The Most Good for Your Company and Your Cause. John Wiley\&Sons.

[33]Wibisono, $\quad$ Yusuf.(2007) Membedah Konsep dan Aplikasi CSR. Gresik: Fascho Publishing.

[34] Wang Fenghua., Lam, Mohica,. Varshney, Sanjay. 2017. Driving Mechanism of Corporate Social
Responsibilt in United States and Mainland China. EJBO Electronic Journal of Business Ethics and Organization Studies: 15-26

[35] Saidi, Zaim,. Abidin, Hamid. 2004. Menjadi Bangsa Pemurah: Wacana dan Praktek Kedermawanan Sosial di Indonesia. Jakarta: Piramedia

[36]Hurairah, Abu. 2008. Pengorganisasian danPengembangan Masyarakat. Bandung: Humaniora

[37]TTPS. 2010. Buku Panduang Tanggung Jawab Sosial Perusahaan (Corporate Social Responsibility-CSR) Sebuah Potensi Alternatif Sumber Pendanaan Sanitasi. Tim Teknis Pembangunan Sanitasi

Tabel 1. Dukungan Penyediaan Tempat Istirahat Dengan Konsep Anjungan Pelayanan Jalan Terhadap Prinsip-Prinsip Berkelanjutan

\begin{tabular}{|c|c|c|c|}
\hline $\begin{array}{c}\text { Pemangku } \\
\text { kepentingan }\end{array}$ & Ekonomi & Sosial & Lingkungan \\
\hline Internal & $\begin{array}{l}\text { Meningkatkan volume } \\
\text { penjualan dan pangsa } \\
\text { pasar } \\
\text { Menarik calon investor }\end{array}$ & $\begin{array}{l}\text { Meningkatkan komunikasi dan } \\
\text { interaksi sosial dengan } \\
\text { masyarakat } \\
\text { Meningkatkan citra positif } \\
\text { perusahaan } \\
\text { Memperoleh dukungan dan } \\
\text { meningkatkan hubungan dengan } \\
\text { masyarakat dan pemerintah } \\
\text { Memperoleh penghargaan }\end{array}$ & $\begin{array}{l}\text { Meningkatkan } \\
\text { kebahagiaan dan } \\
\text { kenyamanan dalam } \\
\text { bekerja secara psikis } \\
\text { dan emosional. } \\
\text { Mempertahankan } \\
\text { sumber daya yang } \\
\text { berkualitas }\end{array}$ \\
\hline Eksternal & $\begin{array}{l}\text { Mengurangi kerugian } \\
\text { akibat kecelakaan } \\
\text { Menyokong dan } \\
\text { meningkatkan } \\
\text { pertumbuhan ekonomi } \\
\text { daerah dan nasional } \\
\text { Meningkatkan } \\
\text { kesejahteraan } \\
\text { masyarakat setempat } \\
\text { melalui peningkatan } \\
\text { kegiatan ekonomi } \\
\text { lokal }\end{array}$ & $\begin{array}{l}\text { Memfasilitasi pemenuhan } \\
\text { kebutuhan dasar manusia } \\
\text { Meningkatkan interaksi } \\
\text { masyarakat lokal dengan } \\
\text { pengguna jalan } \\
\text { Meningkatkan kualitas } \\
\text { pelayanan publik (pelayanan } \\
\text { jalan, kesehatan dan pendidikan } \\
\text { masyarakat } \\
\text { Meningkatkan kesejahteraan } \\
\text { masyarakat setempat melalui } \\
\text { pemberdayaan }\end{array}$ & $\begin{array}{l}\text { Mengurangi dampak } \\
\text { atau resiko akibat } \\
\text { bencana alam }\end{array}$ \\
\hline
\end{tabular}

Tabel 2. Peran Keberadaan Pemangku Kepentingan Dalam Organisasi

\begin{tabular}{lcccc}
\hline Tahapan & \multicolumn{4}{c}{ Peran Pemangku Kepentingan } \\
\cline { 2 - 4 } Program & Perusahaan & Pemerintah & Masyarakat & Lembaga Pengelola \\
\hline
\end{tabular}




\begin{tabular}{|c|c|c|c|c|}
\hline \multicolumn{5}{|l|}{ CSR } \\
\hline Perencanaan & $\begin{array}{l}\text { - Membantu } \\
\text { mengidentifik } \\
\text { asi jenis } \\
\text { aktivitas CSR } \\
\text { yang berkaitan } \\
\text { dengan } \\
\text { dampak } \\
\text { - Menyiapan } \\
\text { pogram dan } \\
\text { rencana } \\
\text { pendanaan } \\
\text { pembangunan }\end{array}$ & $\begin{array}{l}\text { - Menyediakan } \\
\text { regulasi atau } \\
\text { pedoman } \\
\text { perencanaan } \\
\text { tempat istirahat } \\
\text { - Memfasilitasi } \\
\text { penyelesaian } \\
\text { administrasi } \\
\text { perizinan } \\
\text { - Memberikan } \\
\text { masukan dan } \\
\text { pendampingan } \\
\text { dalam proses } \\
\text { perencanaan } \\
\end{array}$ & $\begin{array}{l}\text { - Memberikan } \\
\text { masukan } \\
\text { terkait program } \\
\text { dan rencana } \\
\text { aktivitas } \\
\text { - Menyampaikan } \\
\text { kebutuhan, } \\
\text { data-data dan } \\
\text { kondisi } \\
\text { lingkungan } \\
\text { masyarakat }\end{array}$ & $\begin{array}{l}\text { - Membantu } \\
\text { menyampaikan } \\
\text { konsep rencana } \\
\text { pengelolaan yang } \\
\text { memenuhi standar } \\
\text { kelayakan } \\
\text { - Menyusun prosedur } \\
\text { dan standar } \\
\text { pelayanan minimal } \\
\text { - Menyusun progran } \\
\text { dan rencana } \\
\text { pelaksanaan kegiatan } \\
\text { pengelolaan }\end{array}$ \\
\hline Pelaksanaan & $\begin{array}{l}\text { - Melaksanakan } \\
\text { pembangunan } \\
\text { tempat } \\
\text { istirahat dan } \\
\text { fasilitas } \\
\text { - Melaksanakan } \\
\text { aktivitas CSR } \\
\text { untuk } \\
\text { memperoleh } \\
\text { manfaat bagi } \\
\text { perusahaan }\end{array}$ & $\begin{array}{l}\text { - Menyiapkan tenaga } \\
\text { ahli untuk } \\
\text { pendampingan dan } \\
\text { pengendalian } \\
\text { pembangunan } \\
\text { - Memberikan } \\
\text { masukan pada saat } \\
\text { pelaksanaan } \\
\text { pembangunan } \\
\text { - Melaksanakan } \\
\text { aktivitas } \\
\text { manajemen jalan }\end{array}$ & $\begin{array}{l}\text { - Melaksanakan } \\
\text { aktivitas } \\
\text { - Menerima } \\
\text { manfaat } \\
\text { fasilitas }\end{array}$ & $\begin{array}{l}\text { - Mengelola tempat } \\
\text { istirahat termasuk } \\
\text { fasilitas dan utilitas } \\
\text { yang ada } \\
\text { didalamnya. } \\
\text { - Memberikan } \\
\text { pelayanan kepada } \\
\text { masyarakat } \\
\text { - Mengelola aktivitas } \\
\text { CSR } \\
\text { - Mengelola dan } \\
\text { mengendalikan } \\
\text { pendapatan dan } \\
\text { pengeluaran } \\
\end{array}$ \\
\hline Pengendalian & $\begin{array}{l}\text { - Mengawasi } \\
\text { hasil } \\
\text { pembangunan } \\
\text { dan aktivitas } \\
\text { CSR yang } \\
\text { dilaksanakan }\end{array}$ & $\begin{array}{l}\text { - Mengendalikan } \\
\text { pemanfaatan } \\
\text { tempat istirahat } \\
\text { agar dimanfaatkan } \\
\text { sesuai peruntukan } \\
\text { dan tidak } \\
\text { mengakibatkan } \\
\text { gangguan atau } \\
\text { pelanggaran } \\
\text { terhadap aturan, } \\
\text { nilai, dan prosedur } \\
\text { yang sudah } \\
\text { ditetapkan } \\
\text { - Membantu } \\
\text { menyelesaikan } \\
\text { sengketa atau } \\
\text { permasalahan yang } \\
\text { mencul }\end{array}$ & $\begin{array}{l}\text { - Mengawasi } \\
\text { pelaksanaan } \\
\text { aktivitas CSR } \\
\text { - Memberikan } \\
\text { dukungan } \\
\text { melalui } \\
\text { kemitraan } \\
\text { dengan } \\
\text { perusahaan }\end{array}$ & $\begin{array}{l}\text { - Mengawasi } \\
\text { pengelolaan tempat } \\
\text { istirahat agar tetap } \\
\text { memenuhi standar } \\
\text { pelayanan minimal } \\
\text { - Mengawasi fasilitas } \\
\text { agar sesuai } \\
\text { peruntukannya } \\
\text { - Mengawasi dan } \\
\text { mengendalikan } \\
\text { pemanfaatan } \\
\text { pendapatan atau } \\
\text { dana yang diperoleh } \\
\text { - Mengawasi } \\
\text { pelaksanaan program } \\
\text { atau kegiatan } \\
\text { pengelolaan tempat } \\
\text { istirahat }\end{array}$ \\
\hline
\end{tabular}


Hendra Hendrawan, Penyediaan Tempat Istirahat... 